\title{
PHYTOCHEMICAL SCREENING AND ANTIAMEBIC STUDIES OF TAMARINDUS INDICA OF LEAVES EXTRACT
}

\author{
MANSOUR ABDULNABI H MEHDI ${ }^{*}$, FADEL YS ALARABI ${ }^{1}$, MAZAHAR FAROOQUI ${ }^{2}$, VIDYA PRADHAN ${ }^{1}$
}

${ }^{1}$ Department of Zoology, Dr. Rafiq Zakaria College for Women, Aurangabad - 431001, India. ${ }^{2}$ Departemnt of Chemistry, Dr. Rafiq Zakaria College for Women, Navkhanda, Dr. Babasaheb Ambedkar Marathwada University, Aurangabad - 431001, India. Email: Mansourabdulnabi@gmail.com/drvidyasp@gmail.com

Received: 11 September 2018, Revised and Accepted: 03 November 2018

ABSTRACT

Objective: The present study deals with preliminary phytochemical screening of Tamarindus indica extracts and investigates its antiamebic effect against Entamoeba histolytica in vitro.

Methods: E. histolytica was isolated from stools of patients with amebic dysentery and cultivated in lock-egg medium. The leaves extract was added to check its antiamebic activity.

Results: The phytochemical screening shows that T. indica contains alkaloids, flavonoids, phenol, and tannins. T. indica extracts (aqueous and ethanolic) were added to culture media E. histolytica. It was observed that E. histolytica count reduced to zero after $72 \mathrm{~h}$ and $96 \mathrm{~h}$ when $15 \mathrm{mg} / \mathrm{ml}$ of aqueous and ethanolic extracts were added, respectively. It is also revealed that there is no cytotoxicity against erythrocytes even when high concentration of plant leaves extract is used

Conclusion: The in vitro sensitivity of T. indica leaves extract against the E. histolytica is established.

Keywords: Entamoeba histolytica, Tamarindus indica, Phytochemical.

(C) 2019 The Authors. Published by Innovare Academic Sciences Pvt Ltd. This is an open access article under the CC BY license (http://creativecommons. org/licenses/by/4. 0/) DOI: http://dx.doi.org/10.22159/ajpcr.2019.v12i2.29684

\section{INTRODUCTION}

Entamoeba histolytica has affected 50 million people of the world's population annually with the prevalence of $50 \%$ of the general population it is estimated to cause $>100,000$ deaths per year $[1,2]$. The prevalence of amebiasis varies from $1 \%$ in industrialized countries to $50 \%-80 \%$ in tropical countries [3]. It also represents the second largest cause of mortality from infection with parasitic protozoa after malaria [4]

At present, metronidazole is the therapeutic drug of choice for the treatment of amebiasis [5], but it experiences drug resistance by E. histolytica [6], resulting in the need for increased doses to overcome the infection [7]. However, this drug has several untoward side effects such as headache, metallic taste in the mouth, and vomiting as well as neurotoxicity [8,9]. E. histolytica parasite has registered some level of resistance to most of the medicines rendering them ineffective [10], in addition, the risk of potential mutagenicity, carcinogenicity, and side effects of metronidazole, and taking into account, the development of resistant strains of $E$. histolytica against metronidazole, new, more effective, and safer antiprotozoal agents is urgently required [9,11]. In developing countries, medicinal plants are popular because their products are safe and widely available at low cost [12]. Screening natural products provide the chance to discover new molecules of the unique structure with high activity and selectivity [13]. Therefore, there is a need to find new compounds that can help to curb some of the menaces of resistance and also treat this E. histolytica.

The aim of this study is to perform preliminary phytochemical screening of the Tamarindus indica extracts and to investigate the antiamebic effect of $T$. indica against $E$. histolytica in vitro. In addition, this study aims to investigate cytotoxicity against the erythrocytes for T. indica extracts. According to literature survey, antiamebic activity of this plant has not previously been reported. Therefore, this study could be assumed as the first report on this topic.

\section{MATERIALS AND METHODS}

\section{Collection of plant sample}

T. indica leaves (Fig. 1a) were collected from Rozabagh garden. The collected plant was identified botanically by Dr. Rafiuddin Naser Department of Botany Maulana Azad College, Aurangabad. The leaves were washed well under tap water, then dried in the laboratory in the absence of sunlight and left for two weeks. The leaves were flipped daily to remove damaged leaves and to prevent moisture. When the dried leaves were ready, they were grinded with an electric grinder until they became soft powder. The powder was preserved in bottles at $4^{\circ} \mathrm{C}$ in refrigerator

\section{Preparation of plant extracts}

The following procedures were used to prepare aqueous and ethanolic $70 \%$ extract [14].

\section{Preparation of aqueous extracts}

About $40 \mathrm{~g}$ of dry plant powder was taken in a beaker and $400 \mathrm{ml}$ of distilled water was added. Then, the mixture was stirred with a magnetic stirrer for $24 \mathrm{~h}$. It was then sprayed by four layers of gauze cloth to separate the large fibers. The filter was then separated by centrifuge at $3000 \mathrm{rpm}$ for $10 \mathrm{~min}$. The extract was evaporated by leaving it in an incubator at a temperature of $50^{\circ} \mathrm{C}$ for $24 \mathrm{~h}$. The extract was weighed and kept in refrigerator in sterilized and dark glass containers.

Preparation of ethanolic extracts

About $40 \mathrm{~g}$ of dry plant powder was weighed and transferred to Soxhlet extraction. $400 \mathrm{ml}$ of ethanol was added to it. The plant materials were extracted at $50-55^{\circ} \mathrm{C}$, till the color extract disappeared. The solvent was evaporated by rotary evaporator. The dry mass was transferred to incubator and kept for $24 \mathrm{~h} 50^{\circ} \mathrm{C}$. It was weighed and kept in refrigerator in sterilized and dark colored containers. 


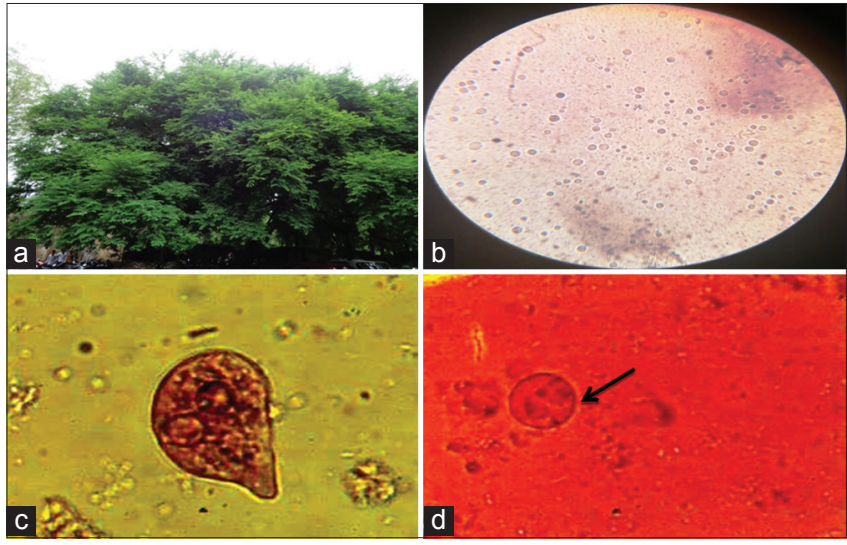

Fig. 1: (a) Tamarindus indica, (b) Entamoeba histolytica growth in some control tubes, (c) Trophozoites stain by Lugol's iodine stain, (d) Cyst stains by eosin stain

Phytochemical tests

The qualitative test for various phytochemical tests was carried out and included alkaloids, flavonoids, glycosides, phenols, filafinun, flavonol, resins, saponins, terpenoids, sterols, tannins, furocoumarins, triterpenoids, amino acids, carbohydrates, and coumarins as per the procedure described in the reference $[14,15]$. The $\mathrm{pH}$ of the extracts was measured as per reference [16].

\section{Materials}

All chemicals used for the preparation of different reagents were of Analar grade from SD Fine Chemical Ltd. Sterilized distilled water was used wherever required. Rice starch solution inactivated human serum, Lock's solution, Ringers solution, and egg slant were prepared as described in the literature [17-22].

\section{Sources of parasite}

The stool samples from patients with amebic dysentery were obtained from public hospitals and some private medical laboratories and delivered to the laboratory within 20-30 min.

\section{Laboratory diagnosis}

Microscopic examination: All stool samples were examined microscopically under high power $(40 x)$ for the detection of the trophozoite and cyst stage of E. histolytica by direct wet mount method with normal saline and Lugol's iodine $[23,24]$.

\section{Cultivation of parasite E. histolytica}

The stool sample taken by of wooden stick or wire loop and the medium was gently mixed to obtain homogeneous distribution. The tubes were incubated vertically at $37^{\circ} \mathrm{C}$ for $48 \mathrm{~h}$ before the examination.

\section{The subculture of parasite $E$. histolytica}

After $48 \mathrm{~h}$ of E. histolytica incubation at $37^{\circ} \mathrm{C}$, a drop was taken and examined directly under the microscope, many subcultures were done when growth was found. Culture tubes were chilled on ice for $5 \mathrm{~min}$ and the upper phase (around $4 \mathrm{ml}$ ) was discarded. These diment parts containing the parasites were mixed and transferred to a fresh sterile culture tube containing the culture medium. This operation was repeated for a further $48 \mathrm{~h}$ permitted to maintain the ameba.

Preparation of ethanolic extract and aqueous extract stock solution

About $1 \mathrm{~g}$ of the aqueous extract obtained was dissolved in $5 \mathrm{ml}$ of sterilized distilled water. It was treated as aqueous stock solution. Similarly, $1 \mathrm{~g}$ of ethanolic extract was dissolved in $5 \mathrm{ml}$ of dimethyl sulfoxide (DMSO). It was treated as stock solution for ethanolic extract. The maximum concentration of DMSO during biological evaluation showed did not exceed $10 \%$ of the level of inhibition of ameba growth occurred [25].
The concentration became $200 \mathrm{mg} / \mathrm{ml}$ for each plant extract. The extracts with concentration $2.5,5,10,15$, and $20 \mathrm{mg} / \mathrm{ml}$ were prepared from the stock solution according to the following equation: $\mathrm{C}_{1} \mathrm{~V}_{1}=\mathrm{C}_{2} \mathrm{~V}_{2}$.

\section{Preparation of parasites}

The density of population of the parasite grown in the medium was counted by hemocytometer and eosin stain (1\%). A drop from between the liquid and the solid of the culture medium parasite was taken and placed on a clean glass slide, and then, a drop of $1 \%$ eosin stain was added. After it was well mixed, $10 \mu \mathrm{l}$ was withdrawn by pipette and placed on a hemocytometer and examined under microscope $(40 \times)$ magnification strongly. The total number of parasites was calculated by applying the following formula:

Total number of parasite=number of parasites in four large squares $\times 2500 \times 2$ [26]. The $80 \times 10^{3}$ cell $/ \mathrm{ml}$ of E. histolytica was added and incubated with the different concentrations of extract plant in lock-egg (LE) medium for $24,48,72$, and $96 \mathrm{~h}$.

\section{Determination of cytotoxicity of $T$. indica extracts}

Rating cellular toxicity of aqueous and ethanol extract of $T$. indica has been determined as per literature [27].

\section{Statistical analysis}

Data were analyzed using general treatment structure (no blocking), factorial experiment, with three replications using GenStat 5.2 at $\mathrm{p} \leq 0.05$ and were considered statistically significant.

\section{RESULTS AND DISCUSSION}

The effectiveness of T. indica on E. histolytica parasite cultured in LE medium has been examined. The test result has been shown in Fig. 1a-c.

\section{In vitro activity of aqueous extract and ethanolic extract of $T$. indica} against E. histolytica

Table 1 shows the effect of aqueous and ethanolic extracts of $T$. indica on E. histolytica in vitro, respectively. The results of the present study show that there are statistically significant differences at $p \leq 0.05$ for different extraction methods of $T$. indica. The ethanolic extract had more effect in reducing the numbers of $E$. histolytica as compared to the aqueous extract. The average number of E. histolytica in the presence of the ethanolic extract was $32.18 \times 10^{3} \mathrm{cell} / \mathrm{ml}$ while the general means of aqueous extract were $37.15 \times 10^{3} \mathrm{cell} / \mathrm{ml}$ (Fig. 2a). This is due to the ability of the substances to become solubility in ethanol more than in the water, and thus, the ability of the ethanol extract is more than aqueous extract in the inhibition of microorganisms.

The aqueous extract had a statistically significant effect at $\mathrm{p} \leq 0.05$ on the reduction of E. histolytica by increasing the concentration and increasing the time (Table 1), compared to the control but less than the ethanolic extract. The concentration of $20 \mathrm{mg} / \mathrm{ml}$ of each of the aqueous and ethanolic extracts for the T. indica shows that $E$. histolytica numbers have decreased to zero after $72 \mathrm{~h}$ of incubation as well as concentrations of 10 and $15 \mathrm{mg} / \mathrm{ml}$ of both aqueous and ethanolic extracts show that E. histolytica numbers have decreased to zero after $96 \mathrm{~h}$ of incubation (Fig. 2b). This is due to the toxic compounds which are present in the extracts and their effect in the ameba cell membrane directly. Through penetrating into the cell, this leads to killing the ameba or affecting the process of synthesis of proteins inside the parasite body [28]. The activity inhibited by ethanolic extract against $E$. histolytica could be the result of the phytochemical constituents present in them. Alkaloids, flavonoids, tannins, and saponins found in ethanolic extract have been known to be responsible for activities such as antimicrobial, analgesic, anti-inflammatory, and antioxidant [29-32]. It is clear that there are no statistically significant differences at $\mathrm{p} \leq 0.05$ between the concentrations of 20,15 , and $10 \mathrm{mg} / \mathrm{ml}$ of aqueous and alcohol extracts ever at time 72 and $96 \mathrm{~h}$. There are also no statistically significant differences between concentrations of 5, 10,15, and $20 \mathrm{mg} / \mathrm{ml}$ of the ethanolic extract after $96 \mathrm{~h}$ of incubation (Fig. 2d). Those terpenes are active against protozoan parasites [33]. This could be the reason for 


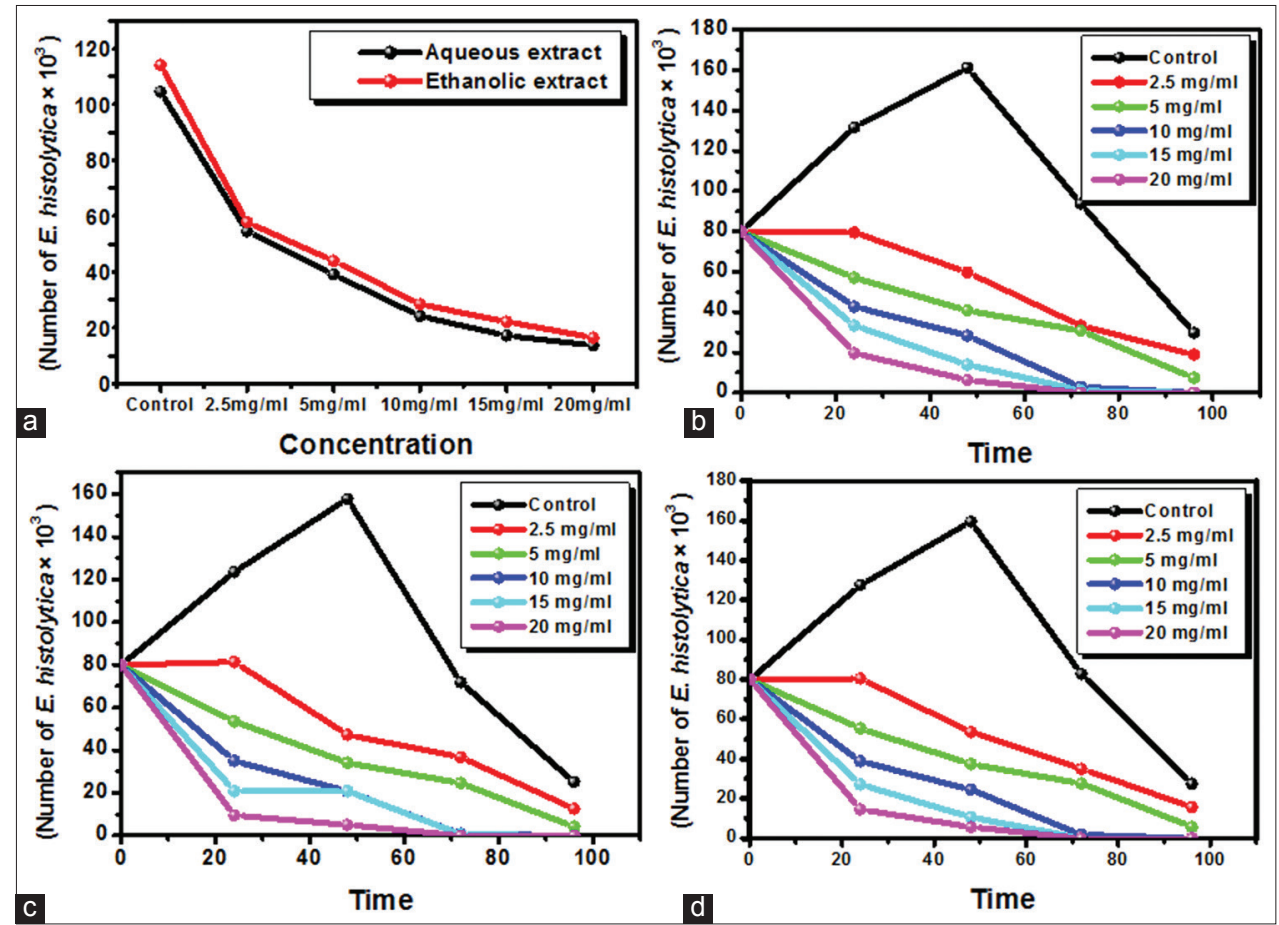

Fig. 2: Variation of the mean number of Entamoeba histolytica with (a) effect of extraction methods, (b) effect of aqueous extract, (c) effect of ethanolic extract, (d) average effect of $T$. indica extracts concentration

Table 1: Effect of aqueous and ethanolic extracts of $T$. indica against $E$. histolytica in vitro

\begin{tabular}{|c|c|c|c|c|c|c|}
\hline \multirow[t]{2}{*}{ Extracts } & \multirow[t]{2}{*}{ Concentration } & \multicolumn{5}{|c|}{ Experimental period (Number of E. histolytica $\times 10^{3}$ ) } \\
\hline & & $24 \mathrm{~h}$ & $48 \mathrm{~h}$ & $72 \mathrm{~h}$ & $96 \mathrm{~h}$ & Means \\
\hline \multirow{6}{*}{ Aqueous } & Control & 131.67 & 161.25 & 93.75 & 29.67 & 104.08 \\
\hline & $2.5 \mathrm{mg} / \mathrm{ml}$ & 79.50 & 59.67 & 33.33 & 18.87 & 47.84 \\
\hline & $5 \mathrm{mg} / \mathrm{ml}$ & 57.03 & 40.77 & 30.70 & 7.27 & 33.94 \\
\hline & $10 \mathrm{mg} / \mathrm{ml}$ & 42.67 & 28.25 & 2.92 & 0.00 & 18.46 \\
\hline & $15 \mathrm{mg} / \mathrm{ml}$ & 33.33 & 13.87 & 1.20 & 0.00 & 12.10 \\
\hline & $20 \mathrm{mg} / \mathrm{ml}$ & 19.67 & 6.25 & 0.00 & 0.00 & 6.48 \\
\hline Means & & 60.64 & 51.68 & 26.98 & 9.30 & 37.15 \\
\hline \multirow[t]{6}{*}{ Ethanolic } & Control & 123.50 & 157.67 & 71.83 & 25.07 & 94.52 \\
\hline & $2.5 \mathrm{mg} / \mathrm{ml}$ & 81.33 & 47.30 & 36.67 & 12.60 & 44.48 \\
\hline & $5 \mathrm{mg} / \mathrm{ml}$ & 53.53 & 34.07 & 24.63 & 4.17 & 29.10 \\
\hline & $10 \mathrm{mg} / \mathrm{ml}$ & 35.00 & 20.80 & 0.83 & 0.00 & 14.16 \\
\hline & $15 \mathrm{mg} / \mathrm{ml}$ & 20.83 & 7.40 & 0.60 & 0.00 & 7.21 \\
\hline & $20 \mathrm{mg} / \mathrm{ml}$ & 9.50 & 5.00 & 0.00 & 0.00 & 3.62 \\
\hline Means & & 53.95 & 45.37 & 22.43 & 6.97 & 32.18 \\
\hline LSD 5\% & & \multicolumn{5}{|c|}{ Extract=3.395, Concentration=5.881, Tim=4.802 } \\
\hline
\end{tabular}

E. histolytica: Entamoeba histolytica, T. indica: Tamarindus indica, LSD: Least significant differences

Table 2: Average variation in habitation capacity of extracts on E. histolytica

\begin{tabular}{llllll}
\hline Concentration & \multicolumn{5}{l}{$\begin{array}{l}\text { Experimental period } \\
\text { (Number of } \boldsymbol{E} \text {. histolytica } \times \mathbf{1 0}^{\mathbf{3}} \text { ) }\end{array}$} \\
\cline { 2 - 6 } & $\mathbf{2 4 \mathbf { h }}$ & $\mathbf{4 8} \mathbf{~ h}$ & $\mathbf{7 2} \mathbf{~ h}$ & $\mathbf{9 6 ~ h}$ & Means \\
\hline Control & 127.58 & 159.46 & 82.79 & 27.37 & 99.30 \\
$2.5 \mathrm{mg} / \mathrm{ml}$ & 80.42 & 53.48 & 35.00 & 15.73 & 46.16 \\
$5 \mathrm{mg} / \mathrm{ml}$ & 55.28 & 37.42 & 27.67 & 5.72 & 31.52 \\
$10 \mathrm{mg} / \mathrm{ml}$ & 38.83 & 24.52 & 1.87 & 0.00 & 16.31 \\
$15 \mathrm{mg} / \mathrm{ml}$ & 27.08 & 10.63 & 0.00 & 0.00 & 9.65 \\
$20 \mathrm{mg} / \mathrm{ml}$ & 14.58 & 5.62 & 0.00 & 0.00 & 5.05 \\
Means & 57.30 & 48.52 & 24.71 & 8.14 & 34.67 \\
LSD 5\% & 11.762 & & & & \\
\hline
\end{tabular}

LSD: Least significant differences, E. histolytica: Entamoeba histolytica the activity exhibited by our plant. It is reported that extracts of plant containing tannins and alkaloids possess activity against diarrheacausing parasite E. histolytica [34].

The activities exhibited by T. indica against E. histolytica could also be attributed to the phytochemical constituents present in $T$. indica.

T. indica is known to contain tannins $[35,36]$ which have been found to be active against diarrhea-causing parasites. Tannins and alkaloids are known to be responsible for anti-inflammatory and antimicrobial activities of some medicinal plants [37]. In diarrheal conditions including amebiasis and giardiasis, inflammation plays a major role by altering the gut sensorimotor function and also compromises the gut walls making it possible for the parasites to permeate [38]. 
Table 3: The phytochemical of ethanolic and aqueous extract of $T$. indica leaves

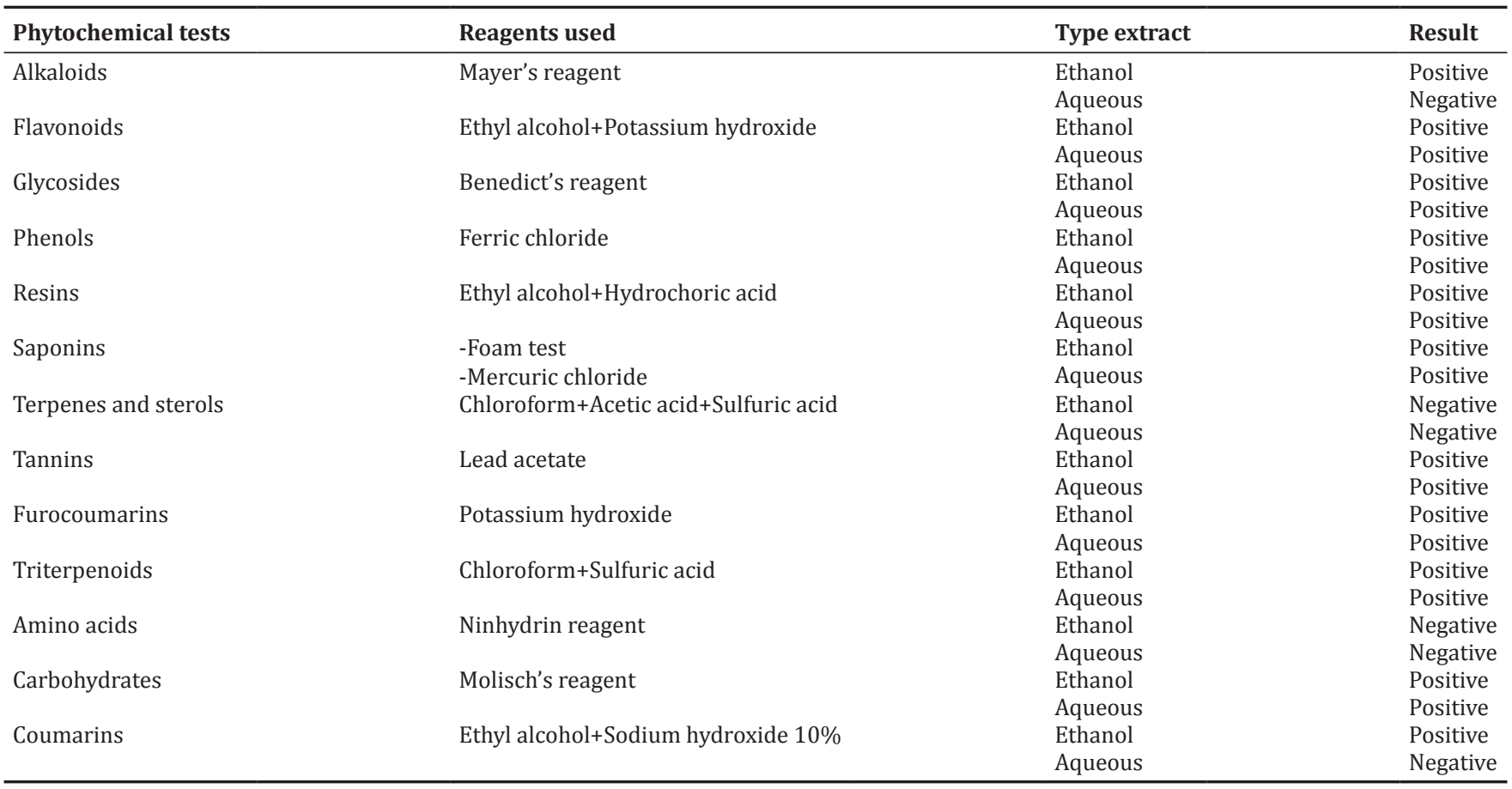

T. indica: Tamarindus indica

The flavonoids found in medicinal plants were responsible for the antiamebic activity [39]. Both the plant extracts exhibited activities against $E$. histolytica have been found to contain flavonoids, and hence, the flavonoids may be responsible for the E. histolytica death. Flavonoids have been distinguished with characteristics in their reactivity with proteins related polyamides polymers for bacteria [40], and there are other mechanisms for growth inhibition of microorganisms by phenolic compounds may be due to iron deprivation or hydrogen bonding with vital proteins [41].

Triterpenes and saponins are also responsible for antiparasite activity and most of the extracts were found to contain saponins [42]. For the ethanolic and aqueous extracts, it is known that triterpenes are found in the leaves [43].

To cheek the interaction between concentrations of extract with respect to time, we have taken average inhibition for aqueous as well as ethanolic extract against it and represented in (Table 2) the following equation:

Average inhibition $=\mathrm{I}_{\mathrm{a}}+\mathrm{I}_{\mathrm{b}} / 2$

Where, $\mathrm{I}_{\mathrm{a}}$ is the aqueous extract inhibition and $\mathrm{I}_{\mathrm{b}}$ is the ethanolic extract inhibition.

In the present study, it has been shown that the interaction between time and concentration (Table 2) has a significant effect at $\mathrm{p} \leq 0.05$ on decreasing $E$. histolytica number in culture. The concentrations of 15 and $20 \mathrm{mg} / \mathrm{ml}$ decreased E. histolytica number to zero at time of $72 \mathrm{~h}$ of incubation, and the concentration of $10 \mathrm{mg} / \mathrm{ml}$ decreased the E. histolytica number to zero at time of $96 \mathrm{~h}$ of incubation. Furthermore, there are no statistically significant differences at $p \leq 0.05$ at 24 and $48 \mathrm{~h}$ for $20 \mathrm{mg} / \mathrm{ml}$ concentration as well as for $10 \mathrm{mg} / \mathrm{ml}$ concentration at 72 and $96 \mathrm{~h}$ (Fig. 2e). It was observed that the higher concentration yielded higher severity scores than the lower concentration for all the extracts. It was also observed that effects of compounds were proportional to the time. The longer the time of incubation, the more pronounced the effects. This may be due to the fact that an increase in time leads to an increase in the penetration of the active substances of the parasite membranes, and then, these substances destroy them or cause the parasite to become weak. Furthermore, high concentration provides more space to influence the parasite than the lower concentration. This could be done through the interpenetration of this concentration with the external membrane of the parasite. This could affect the tubulins present in the membrane. This concentration made a hole in the membrane which led to the exodus of the parasite's contents and then led to its death.

\section{Phytochemical screening of $T$. indica leaves extracts}

From the phytochemical screening, T. indica (Table 3) was found to contain flavonoids, glycosides, phenols, resins, saponins, tannins, furocoumarins, triterpenoids, and carbohydrates in both extracts. The ethanolic extract contains alkaloids and coumarins while aqueous extract does not contain alkaloids and coumarins as in line with the reported elsewhere [44] but differs in the detection of tannins and flavonoids (in aqueous leaves extract) which was found to be absent in all the extracts during the experiment. It is in agreement with Nwodo et al.[45] but differs in glycosides and flavonoids which were found to be absent in aqueous leaves extract. Furthermore, Abukakar, et al.[36] reported the presence of alkaloids in the aqueous leaves extract, but in contradiction, it was absent in this study. These differences may be due to the difference in geographical locations and environmental conditions of the place where the plant materials were obtained or the use of methods was different in extraction [46].

These results indicate the ability of water and ethanol to extract many active substances. The containment of the T. indica plant on the abovementioned chemicals enhances the possibility of using it medically to treat many diseases.

\section{pH evaluation $T$. indica extracts}

The $\mathrm{pH}$ values of the aqueous and ethanolic extract of $T$. indica plant indicate (Table 4) the acidity of these extracts in general. It shows that the ethanolic extract of $T$. indica leaves has the higher acid value than the aqueous extract. The $\mathrm{pH}$ of the ethanolic extract was 2.85 while the $\mathrm{pH}$ of the aqueous extract was 3.75 .

The low $\mathrm{pH}$ of the extracts may reflect the presence of high levels of oxalic acid, ascorbic acid, and, particularly, a tartaric acid which is 


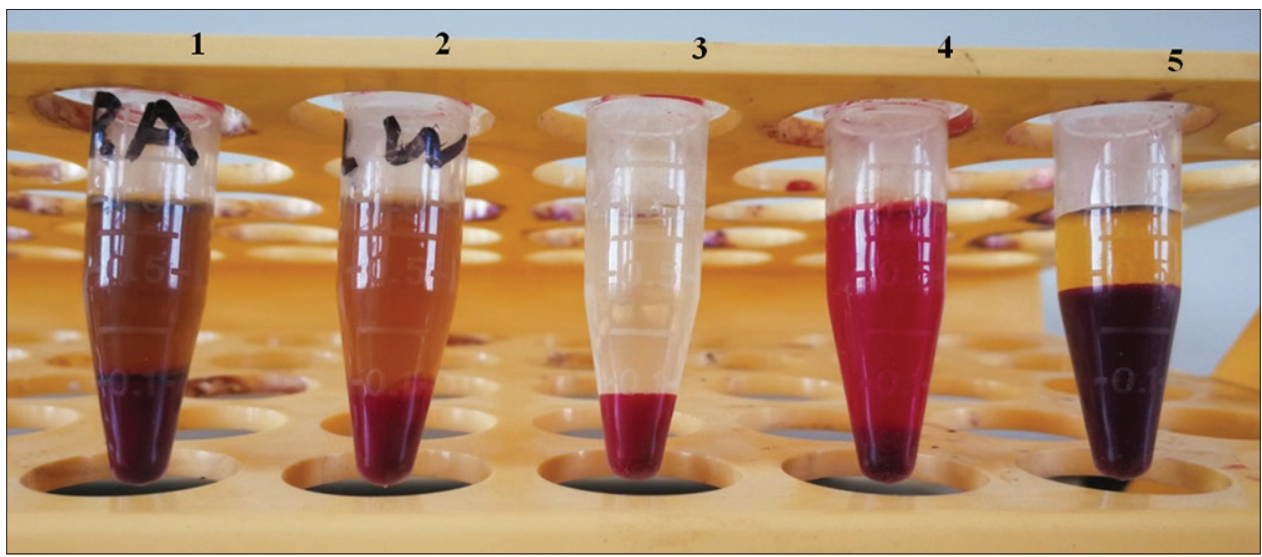

Fig. 3: The cytotoxicity of $T$. indica extracts

Table 4: pH evaluation T. indica extracts

\begin{tabular}{ll}
\hline Type of extract & PH \\
\hline Ethanolic extract & 2.85 \\
Aqueous extract & 3.75 \\
\hline
\end{tabular}

Table 5: Determination of the cytotoxicity of $T$. indica extracts

\begin{tabular}{lllll}
\hline Hemolysis & & & & \\
\hline $\mathbf{1}$ & $\mathbf{2}$ & $\mathbf{3}$ & $\mathbf{4}$ & $\mathbf{5}$ \\
\hline Ethanolic & Aqueous & Normal & Tap & Blood \\
Extract & Extract & Saline & Water & Only \\
- & - & - & + & - \\
\hline
\end{tabular}

-=No hemolysis, $+=$ Hemolysis

an unusual plant acid [47]. It is noted from the results that there is a difference between the aqueous and ethanolic extracts of the T. indica, indicating that there is a difference between chemical components dissolved in water than those dissolved in ethanol. pH can be considered as E. histolytica agent because it cannot grow in the acidic environment. The optimal $\mathrm{pH}$ value of E. histolytica is 7-7.2.

Acidity may not play an essential role in the elimination of E. histolytica parasite when low concentrations are used in vitro experiments during a relatively short exposure period as in the current research. Low concentrations cannot make a significant change in the medium in which the E. histolytica lives. The importance of conducting cytotoxicity tests in determining the highest concentrations in which acidity plays an effective role can be used as a therapeutic dose against the pathogen which has no harmful side effects.

\section{Determination of cytotoxicity of $\boldsymbol{T}$. indica extracts}

The results in (Table 5) show that T. indica extract has no cytotoxicity against the erythrocytes in the concentration tested $(20 \mathrm{mg} / \mathrm{ml})$, compared with the negative control tube which contains blood only and with the positive control tube which contains tap water. The extracts showed no aggregation inside the blood cells (Fig. 3).

\section{CONCLUSION}

The ethanolic extract and aqueous extract of T. indica used in this study possessed antiamebic activity in vitro. It showed that the ethanolic extract has the strongest antiamebic activity compared to the aqueous extract. It was concluded that these ethanolic and aqueous extracts could be sources of new antiparasitic agents. Thus, there is a need to perform bioactivity-guided isolation and characterization of the active compounds responsible for the antiparasitic activities previously mentioned.

\section{AUTHORS' CONTRIBUTION}

Mansour A. H. M. has carried out experiments and analyzed results, Fadel Y. S. A. has analyzed results, Mazahar F. has analyzed and written manuscript, and Vidya P. has guided and supervise research and written the experimental part.

\section{CONFLICTS OF INTEREST}

The authors declare that they have no conflicts of interest.

\section{REFERENCES}

1. Ximénez C, Morán P, Rojas L, Valadez A, Gómez A. Reassessment of the epidemiology of amebiasis: State of the art. Infect Genet Evol 2009;9:1023-32:

2. Abhyankar MM, Shrimal S, Gilchrist CA, Bhattacharya A, Petri WA. The Entamoeba histolytica serum-inducible transmembrane kinase EhTMKB1-9 is involved in intestinal amebiasis. Int J Parasitol Drugs Drug Resist 2012;2:243-8.

3. Araujo J, Garcia ME, Diaz-Suarez O, Urdaneta H. Amebiasis: Importance of the diagnosis and treatment. Minireview. Invest Clin 2008;49:265-71.

4. Parija SC, Khairnar K. Mutation detection analysis of a region of 16S-like ribosomal RNA gene of Entamoeba histolytica, Entamoeba dispar, and Entamoeba moshkovskii. BMC Infect Dis 2008;8:131.

5. Issa R. Tropical parasitic lung diseases. Int J Pharm Pharm Sci 2015;7:2-12

6. WassmannC, Hellberg A, Tannich E, Bruchhaus I. Metronidazole resistance in the protozoan parasite Entamoeba histolytica is associated with increased expression of iron-containing superoxide dismutase and peroxiredoxin and decreased expression of ferredoxin 1 and flavin reductase. J Biol Chem 1999;274:26051-6.

7. Conde-Bonfil MD, de la Mora-Zerpa C. Entamoeba histolytica: Un desafío vigente. Salud Pública Méx 1992;34:335-41.

8. Bendesky A, Menéndez D. Metronidazole: Ulna visión integral. Rev Fac Med UNAM 2001;44:255-9.

9. Bautista E, Calzada F, Ortega A, Yépez-Mulia L. Antiprotozoal activity of flavonoids isolated from Mimosa tenuiflora (FabaceaeMimosoideae). J Mex Chem Soc 2011;55:251-3?

10. Quintanilla-Licea R, Mata-Cárdenas BD, Vargas-Villarreal J, Bazaldúa-Rodríguez AF, Kavimngeles-Hernández I, GarzaGonzález JN, et al. Antiprotozoal activity against Entamoeba histolytica of plants used in northeast Mexican traditional medicine. Bioactive compounds from Lippia graveolensand Ruta chalepensis. Molecules 2014;19:21044-65

11. Singh S, Bharti N, Mohapatra PP. Chemistry and biology of synthetic and naturally occurring antiamoebic agents. Chem Rev 2009;109:1900-47.

12. Sawangjaroen N, Sawangjaroen K, Poonpanang P. Effects of Piper longum fruit, Piper sarmentosum root and Quercus infectoria nut gall on caecal amoebiasis in mice. J Ethnopharmacol 2004;91:357-60.

13. Newman DJ, Cragg GM. Natural products as sources of new drugs over the 30 years from 1981 to 2010. J Nat Prod 2012;75:311-35.

14. Harborne JB. Phytochemical Methods. $2^{\text {nd }}$ ed. NewYork: Champon and Hall London; 1984. p. 288

15. Harborne J. Phytochemical Methods, a Guide to Modern Techniques 
of Plant Analysis. London: Chapman and Hall publications, Ltd.; 1973. p. $159-65$.

16. NewallCA, Anderson LA, Phillipson JD. Herbal Medicines. A Guide for Health-care Professionals. London, UK: Pharma Press; 1996. p. 296

17. Jones WR. The experimental infection of rats with Entamoeba histolytica; with a method for evaluating the anti-amebic properties of new compounds. Ann Trop Med Parasitol 1946;40:130-40.

18. Hallman FA, Michaelson JB, De Lamater JN. The cultivation of Endamoeba histolytica in a defined medium1, 2. Am J Trop Med Hyg 1950;1:363-9.?

19. Harinasuta $\mathrm{C}$, Harinasuta $\mathrm{T}$. Studies on the growth in vitro of strains of Entamoeba histolytica. Ann Trop Med Parasitol 1955;49:331-50.

20. Garvey JS, Cremer NE, Sussdorf DH. Methods in Immunology. $3^{\text {rd }}$ ed. Canada: W.A. Benjamin Inc.; 1981. p. 297.

21. Clark CG, Diamond LS. Methods for cultivation of luminal parasitic protists of clinical importance. Clin Microbiol Rev 2002;15:329-41

22. Brand TV, Rees CW, Jacobs L, Reakdon LV. Studies on reducing substances and gas formation in cultures of Endamoeba histolytica and a single species of symbiotic bacteria. Am J Hyg 1943;37:310-19.

23. Obulesu G, Hanumanthappa AR, Reddy PE. A study of stool sample from HIV positive and HIV negative at Andhra Pradesh. Asian J Pharm Clin Res 2018;11:394-7.

24. GillinFD, Reiner DS, Suffness M. Bruceantin, a potent amoebicide from a plant, Bruceantidysenterica. Antimicrob Agents Chemother 1982;22:342-5.

25. Issa R. Non-pathogenic protozoa (review article). Int J Pharm Pharm Sci 2104;3:30-40.

26. Hansen BE. Sample splitting and threshold estimation. Econometrica 2000;68:575-603.

27. He XG, Mocek U, Floss HG, Cáceres A, Girón L, Buckley H, et al. An antifungal compound from Solanum nigrescens. J Ethnopharmacol 1994;43:173-7.

28. Metspalu L, Hiiesaar K, Jõudu J, Kuusik A. The Effects of Certain Toxic Plant Extracts on the Larvae of Colorado Potato Beetle, Leptinotarsa decemlineata(SAY). Tartu, Estonia: In Proceedings of the International Workshop; 2001. p. 24-5.

29. Ateufack G, Yousseu WN, Feudjio BD, Sama LF, Kuiate J, Kamanyi A. Antidiarrheal and in vitro antibacterial activities of leaves extracts of Hibiscus asper. Hook. F. (malvaceae). Asian J Pharm Clin Res 2014;7:130-6?

30. Fiori GL, Fachin AL, Correa VS, Bertoni BW, Giuliatti S, Amui SF, Pereira AS. Antimicrobial activity and rates of tannins in Stryphnodendron adstringens Mart. Accessions collected in the Brazilian Cerrado. Am J Plant Sci 2013;4:2193-8:

31. MuruganT, Wins JA, Murugan M. Antimicrobial activity and phytochemical constituents of leaf extracts of Cassia auriculata. Indian J Pharm Sci 2013;75:122-5.
32. Irfan M, Ahmed S, Sharma M. Antimicrobial activity of terpenoids from Sphaeranthus indicus. L. Asian J Plant Sci Res 2014;4:1-6.

33. Sülsen VP, Cazorla SI, Frank FM, Laurella LC, Muschietti LV, Catalan CA, et al. Natural terpenoids from Ambrosia species are active in vitro and in vivo against human pathogenic trypanosomatids. PLoS Negl Trop Dis 2013;7:2494.

34. McGaw LJ, Jäger AK, Van Staden J. Antibacterial, anthelmintic and antiamoebic activity in South African medicinal plants. J Ethnopharmacol 2000;72:247-63:

35. Padalia H, Moteriya P, Chanda S. Phytochemical analysis and effect of solvents on antibacterial activity of Tamarindus indica Leaf and stem. Int J Curr Eng Technol 2015;5:2716-21.

36. Abukakar MG, Ukwuani AN, Shehu RA. Phytochemical screening and antibacterial activity of Tamarindus indica pulp extract. Asian J Biochem 2008;3:134-8.

37. XuHX, Lee SF. Activity of plant flavonoids against antibiotic-resistant bacteria. Phytother Res 2001;15:39-43.

38. Hill DR. Issues in diagnosis and management. Infect Dis Clin N Am 1993; 7:503-25.

39. Bolaños V, Díaz-Martínez A, Soto J, Rodríguez MA, LópezCamarillo C, Marchat LA, et al. The flavonoid (-)-epicatechin affects cytoskeleton proteins and functions in Entamoeba histolytica. J Proteomics 2014;111:74-85?

40. Haslam E. Natural polyphenols (vegetable tannins) as drugs: Possible modes of action. J Nat Prod 1996;59:205-15.

41. Scalbert A. Antimicrobial properties of tannins. Phytochemistry1991;30:3875-83.

42. Kamanzi AK, Schmid C, Brun R, Kone MW, Traore D. Antitrypanosomal and antiplasmodial activity of medicinal plants from Cote d'Ivoire. J Ethnopharmacol 2004;90:221-7.

43. Adu-Amoah L, Agyare C, Kisseih E, Ayande PG, Mensah KB. Toxicity assessment of Erythrophleum ivorense and Parquetina nigrescens. Toxicol Rep 2014;1:411-20.

44. ChigurupatiS, Yiik E, Mohammad J, Vijayabalan S, Selvarajan K, Reddy $\mathrm{V}$, et al. Screening antimicrobial potential for Malaysian originated Tamarindus indica ethanolic leaves extract. Asian J Pharm Clin Res 2018;11:361-3.

45. Nwodo UU, Obiiyeke GE, Chigor VN, Okoh AI. Assessment of Tamarindus indica extracts for antibacterial activity. Int J Mol Sci 2011;12:6385-96?

46. Kubmarawa D, Ajoku GA, Enwerem NM, Okorie DA. Preliminary phytochemical and antimicrobial screening of 50 medicinal plants from Nigeria. Afr J Biotechnol 2007;6:1690-6.

47. Hossen SM, Hoque ME, Hossain MR, Reza HM, Mainuddin MA, Barua A, et al. In vitro evaluation of antibacterial, thrombolytic and cyto-toxic property of ethanol, acetone and DM water extract of Tamarindus indica Linn. Seeds and its qualitative phyto-chemical investigation. Eur J Sci Res 2011;78:643-50.] 